\title{
Age of the Most Extensive Glaciation of Northern Switzerland: Evidence from the scientific drilling at Möhliner Feld
}

\author{
Dorian Gaar, Frank Preusser
}

\begin{abstract}
Addresses of authors: Dorian Gaar, Institute of Geological Sciences and Oeschger Centre for Climate Change Research, University of Bern, Baltzerstrasse 1+3, 3012 Bern, Switzerland; present address: Baugeologie und Geo-Bau-Labor AG, Bolettastrasse 1, 7000 Chur, E-Mail: gaar@baugeologie.ch; Frank Preusser, Institute of Earth and Environmental Science, University of Freiburg, Alberstraße 23b, 79104 Freiburg, Germany, E-Mail: frank.preusser@geologie.uni-freiburg.de
\end{abstract}

Keywords: $\quad$ Alps, Quaternary, Pleistocene, glaciation, chronology, loess

\section{Introduction}

Möhliner Feld is a key area in the Swiss Pleistocene stratigraphy of the Northern Alpine Foreland. It is located at the River Rhine, about $20 \mathrm{~km}$ east of the city of Basel, and its topography sticks out from the Low Terrace surrounding on the northern flank (Fig. 1). Already Gutzwiler (1894) describes till outcropping in the still open gravel pit 'Bünten' and interprets a shallow ridge on Möhliner Feld as a terminal moraine formed by an alpine glacier advancing from the East. PENCK \& BRÜCKNER (1901-1909) follow this conclusion and describe another, slightly more exterior, terminal moraine. This ridge is interpreted to result from a glacier tongue within the Rhine Valley and is assigned to the Rissian glaciation, the penultimate glaciation in the classical Alpine stratigraphy. The Rissian is usually correlated to Marine Isotope Stage (MIS) 6, i.e. an age of 180-140 ka.

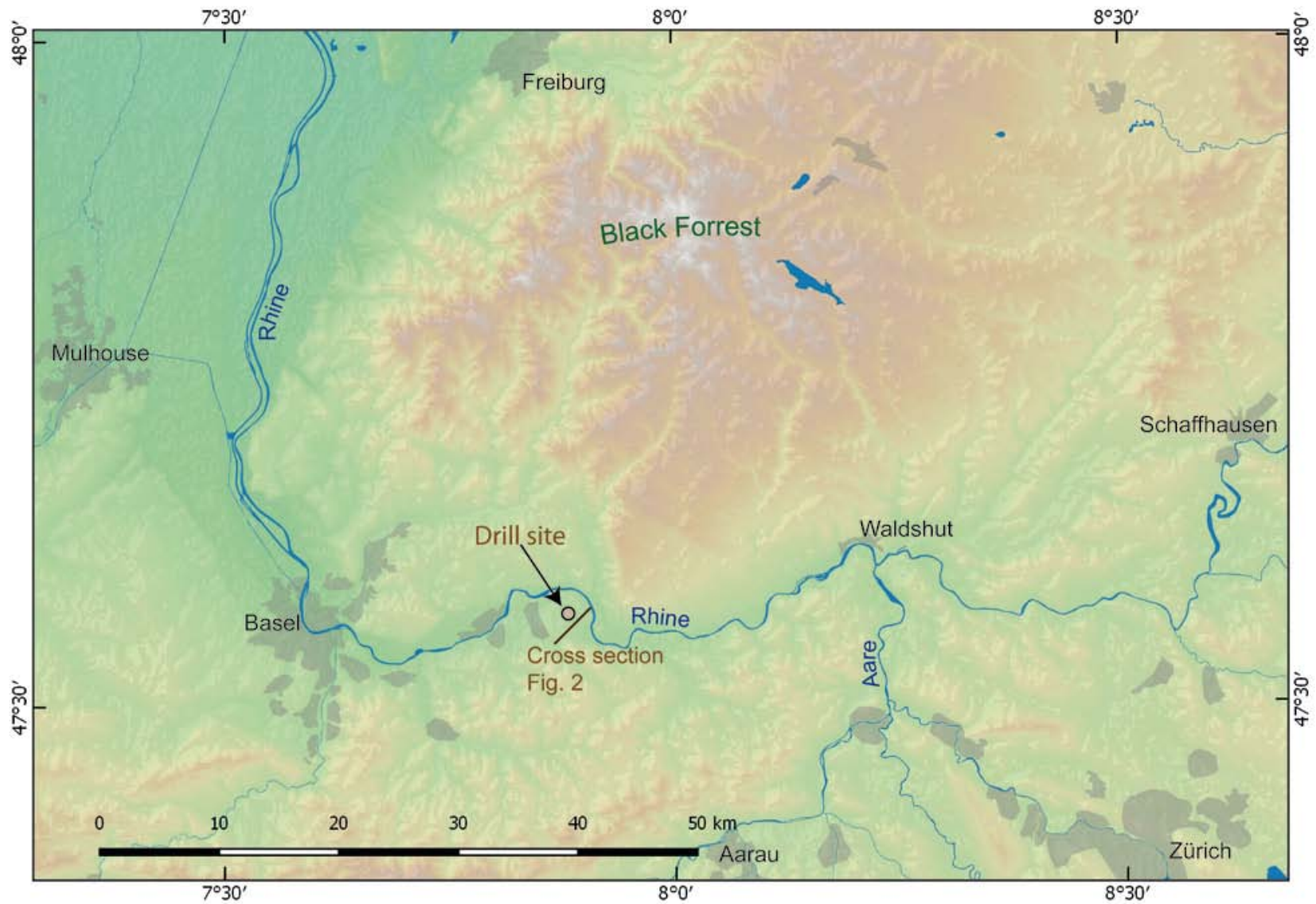

Fig. 1: Overview map of the study area with location of the drill site. / Abb. 1: Übersichtskarte des Untersuchungsgebietes mit Lage der Bohrstelle. 


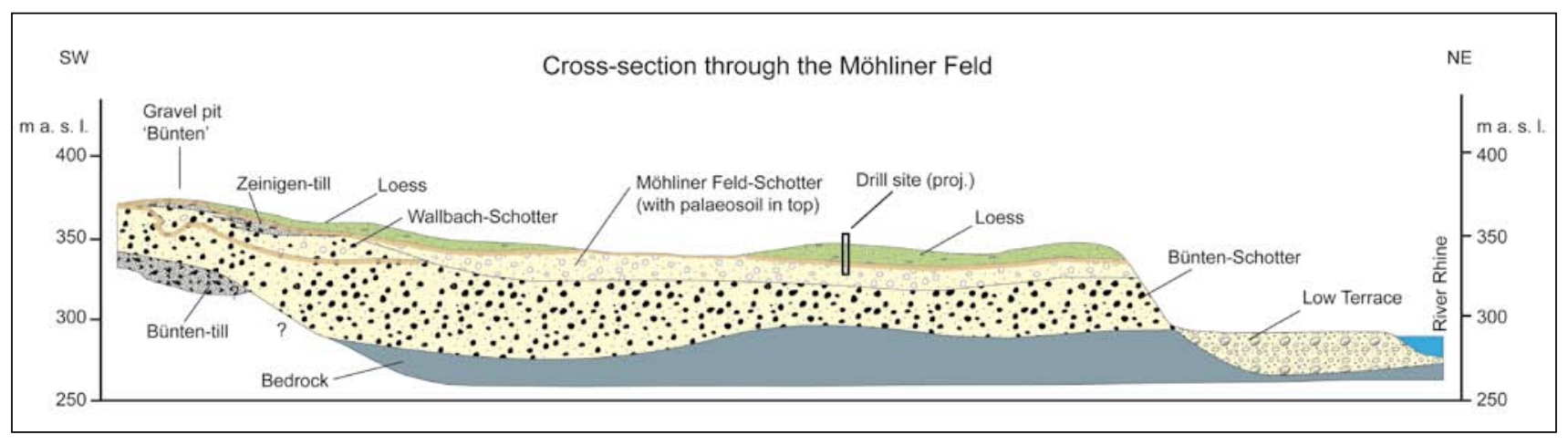

Fig. 2: Cross section through Möhliner Feld with the geological setting elaborated by GRAF (2009).

Abb. 2: Profil durch das Möhliner Feld mit dem geologischen Rahmen wie von GRAF (2009) ausgeabreitet.

A schematic log of the gravel pit 'Bünten' by Dick et al. (1996) shows till containing Alpine material $30 \mathrm{~m}$ below surface (not accessible today). This till is overlain by two glaciofluvial aggradations separated by a palaeosol, topped by weathered till ca. $5 \mathrm{~m}$ below surface and covered by loess (Fig. 2). This weathered till does not show any Alpine material, but consists completely of crystalline components from the Black Forest, north of Möhliner Feld. This evidence indicates two ice advances reached Möhliner Feld, the first from the Alps, the second from the Black Forest, separated by soil development during interglacial or interstadial conditions. GRAF (2009) compiles borehole data from the Möhliner Feld, partly directly located on top of the ridges, but in none of the drillings glacigenic material was identified (Fig. 2). The ridges rather contain up to $10 \mathrm{~m}$ thick silty material, which is interpreted as loess. The underlying gravel, mainly composed of Black Forest material, is noticeably weathered in the uppermost $2-3 \mathrm{~m}$, implying a substantial time-lag between its deposition and accumulation of the loess. The abundant loess cover of Möhliner Feld is possibly explained by a special phenomenon in the area, the 'Möhlin Jet'. The Möhlin Jet is a wind of southern direction that develops mainly in winter when cold air in the Swiss Lowlands overflows the eastern Jura Mountains and dries while falling down into the Rhine valley. In the area of Möhliner Feld the wind speed reaches typically 5 to $10 \mathrm{~m} \mathrm{~s}^{-1}$ and this phenomenon is likely to have occurred also during Pleistocene glaciations. Together with the geological evidence this leads to the hypothesis that the ridges of the Möhliner Feld may rather represent aeolian dunes than glacial features.
Möhliner Feld is considered as marking the Most Extensive Glaciation (MEG) of the Swiss Northern Alpine Foreland. In fact, although the morphology is not glacial, the lowermost till in the gravel pit Bünten is evidence for the presence of Alpine glaciers in an area well beyond the boundaries of the last glacial maximum. The timing of this MEG, however, remains speculative. Schlüchter (2004) states that the MEG ice advance stratigraphically postdates the Early Pleistocene 'Deckenschotter' (gravel sheet) aggradations and pre-dates the loess cover of the Möhliner Feld. At the Thalgut site close to the Alpine border, till overlying bedrock and lacustrine sediments are interpreted based on magnetostratigraphy being located just above the Brunhes/Matuyama boundary. ScHLÜchter (2004) therefore concludes that the MEG 'occurred close to, but clearly after this last magnetostratigraphical reversal'. However, it is not stated where the magnetostratigraphic reversal has been identified and how the findings from Thalgut indicate an extent of the corresponding glaciation at Möhliner Feld.

This report focuses on a drill core penetrating the loess cover of the glacial deposits on Möhliner Feld, with the aim to constrain the age of the loess deposition by luminescence dating and by this better establish the minimum age for the glacial deposits.

\section{Methods}

A rotary core drilling (diameter $=203 \mathrm{~mm}$ ) was lowered on the 'crest' of the inner ridge (Fig. 2, coordinates $\left.47^{\circ} 34^{\prime} 5.00^{\prime \prime} \mathrm{N}, 7^{\circ} 52^{\prime} 53.60^{\prime} \mathrm{E}\right)$. It reached a depth of $12.3 \mathrm{~m}$. The core was placed in core boxes and logged on site simul-

Table 1: Results of high-resolution gamma-spectrometry, resulting dose rates and ages. Weff: effective water content for dose-rate calculation, DR Q: dose-rate of quartz, DR PM: dose rate of polyminerals.

\begin{tabular}{|c|c|c|c|c|c|c|c|c|c|}
\hline Sample & $\begin{array}{c}\text { Depth } \\
\text { [m] }\end{array}$ & $\begin{array}{c}K \\
{[\%]}\end{array}$ & $\begin{array}{c}\text { Th } \\
\text { [ppm] }\end{array}$ & $\begin{array}{c}U \\
\text { [ppm] }\end{array}$ & $\begin{array}{l}W_{\text {eff }} \\
{[\%]}\end{array}$ & $\begin{array}{c}\text { DR Q } \\
\text { [Gy ka-1] }\end{array}$ & $\begin{array}{c}\text { DR PM } \\
\text { [Gy ka-1] }\end{array}$ & OSL [ka] & IR50 [ka] \\
\hline Möh 1 & 1.3 & $1.59 \pm 0.03$ & $11.71 \pm 0.22$ & $3.38 \pm 0.08$ & $25 \pm 5$ & $3.08 \pm 0.26$ & $3.34 \pm 0.27$ & $19.5 \pm 1.8$ & $19.1 \pm 1.6$ \\
\hline Möh 2 & 3.0 & $1.25 \pm 0.02$ & $9.86 \pm 0.32$ & $3.00 \pm 0.06$ & $24 \pm 5$ & $2.58 \pm 0.23$ & $2.81 \pm 0.23$ & $34.6 \pm 3.1$ & $31.3 \pm 2.7$ \\
\hline Möh 3 & 3.8 & $1.23 \pm 0.02$ & $9.93 \pm 2.57$ & $2.96 \pm 0.04$ & $22 \pm 5$ & $2.58 \pm 0.23$ & $2.82 \pm 0.23$ & $33.2 \pm 3.2$ & $32.3 \pm 3.1$ \\
\hline Möh 4 & 5.0 & $1.24 \pm 0.02$ & $10.38 \pm 0.29$ & $3.02 \pm 0.04$ & $21 \pm 5$ & $2.65 \pm 0.33$ & $2.89 \pm 0.24$ & $33.5 \pm 4.3$ & $34.1 \pm 3.2$ \\
\hline Möh 5 & 5.7 & $1.53 \pm 0.03$ & $12.79 \pm 0.30$ & $3.56 \pm 0.09$ & $21 \pm 5$ & $3.20 \pm 0.28$ & $3.48 \pm 0.29$ & $31.0 \pm 3.4$ & $43.0 \pm 3.6$ \\
\hline Möh 6 & 6.8 & $1.35 \pm 0.03$ & $10.54 \pm 0.30$ & $2.80 \pm 0.03$ & $17 \pm 5$ & $2.78 \pm 0.24$ & $3.02 \pm 0.25$ & $68.1 \pm 6.9$ & $58.1 \pm 5.9$ \\
\hline
\end{tabular}




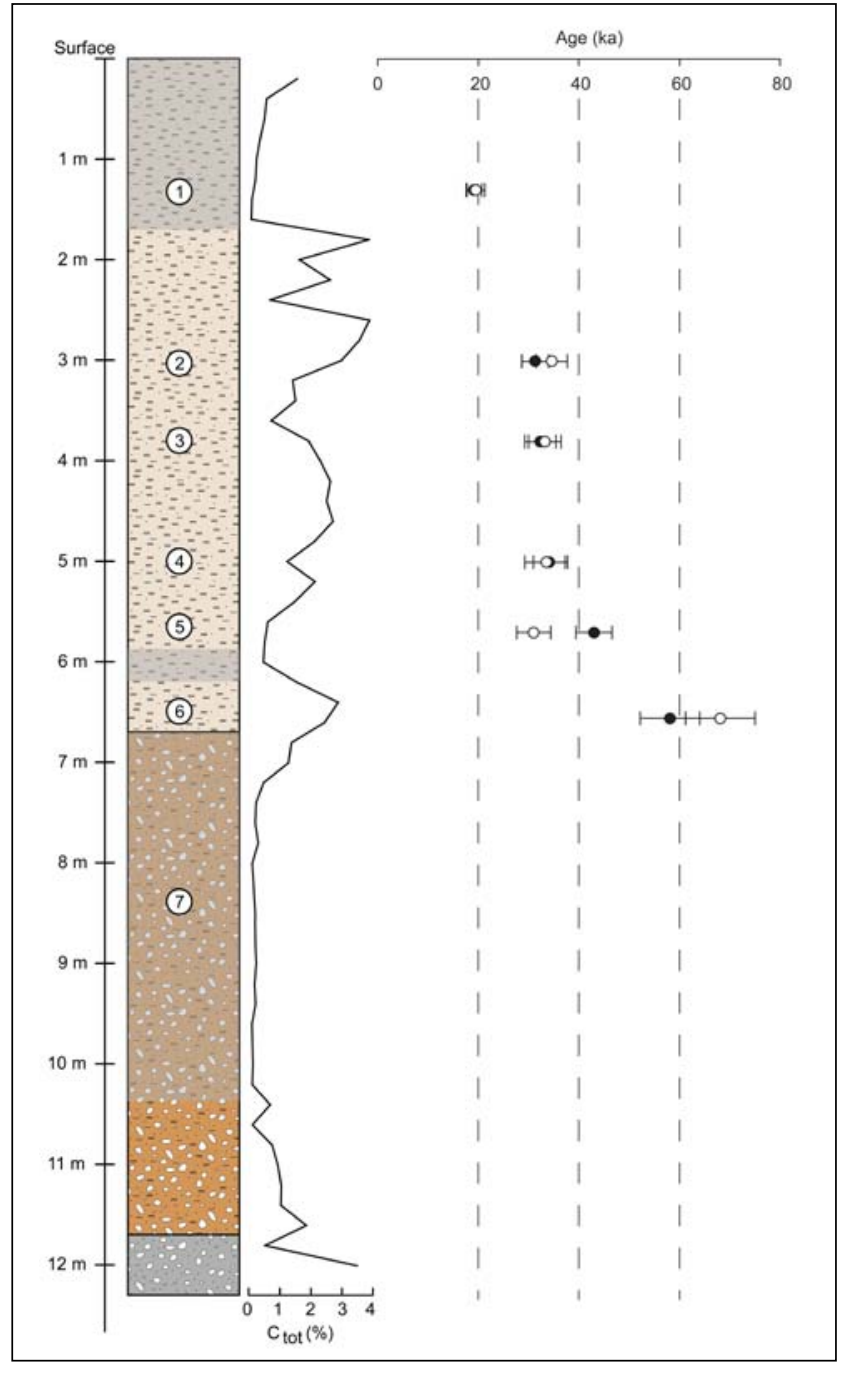

Fig. 3: Drilling profile with carbon content as well as OSL (open symbol) and IRSL ages (closed symbols).

Abb. 3: Bohrprofil mit Kohlenstoffgehalt sowie OSL- (offene Symbole) und IRSL-Altern (ausgefüllte Symbole).

taneously to the drilling progress. Seven samples were taken for luminescence dating, concentrated on the upper part of the core (Fig. 3, Table 1). It was assured that the samples were taken as compact cylinders of ca. $20 \mathrm{~cm}$ length in order to have enough non bleached material for luminescence dating. Additionally, along the whole core every
$20 \mathrm{~cm} \mathrm{ca} .400 \mathrm{~g}$ of material were taken for other laboratory tests, i.e. granulometry using a Malvern Hydro $2000 \mathrm{~S}$ Mastersizer, and total carbon $\left(\mathrm{C}_{\text {total }}\right)$ measurements using a Bruker G4 Icarus CS TF element analyser.

All luminescence sample preparation was performed under subdued red light and the light-exposed outer rim was amply removed with a knife, and only the innermost part (ca. $5 \times 5 \times 5 \mathrm{~cm}$ ) was used for dating. Water content was assessed by drying the samples in an oven at $50^{\circ} \mathrm{C}$ until constant mass was reached. Samples were decarbonatised using $\mathrm{HCl}(32 \%)$ and subsequently organic components were removed with $\mathrm{H}_{2} \mathrm{O}_{2}(30 \%)$. Samples Möh 1, 2, 3, 4 and 5 showed mediocre, Möh 6 and 7 a strong exothermal reaction to $\mathrm{H}_{2} \mathrm{O}_{2}$. The latter two beakers were placed in water to discharge heat. However, sample Möh 7 developed such a high temperature that is was decided to discard this sample, because an effect on the luminescence signal could not be excluded. The remaining samples were washed with deionised water and stored in a $\mathrm{C}_{2} \mathrm{Na}_{2} \mathrm{O}_{4}$-solution to prevent coagulation of particles. The grain size fraction $4-11 \mu \mathrm{m}$ was separated using the Atterberg settling technique following Stoke's law (cf. Frechen et al. 1996). Half of the fraction 4-11 $\mu \mathrm{m}$ was left in $\mathrm{H}_{2} \mathrm{SiF}_{6}(34 \%)$ for ten days in order to dissolve feldspar grains and obtain a purified quartz separate. Subsequently, the quartz fraction was treated with $\mathrm{HCl}(32 \%)$ and washed with deionised water. Aliquots for luminescence measurements were prepared by settling ca. $2 \mathrm{mg}$ of sample material dispersed in $1 \mathrm{ml}$ of acetone onto stainless steel discs until all acetone evaporated.

The outer part of the sediment cylinders was used for determination of the external dose rate. It was dried, disaggregated in a mortar and bulk samples of ca. $450 \mathrm{~g}$ were filled into Marinelli beakers. After a storage time of minimum 30 days to allow for Rn-equilibrium to establish, the dose-rate relevant elements $(\mathrm{U}, \mathrm{K}, \mathrm{Th})$ were measured using high-resolution $\gamma$-spectrometry (Table 1$)$. There is no indication for a disequilibrium in the Uranium decay chain when comparing the activities of ${ }^{238} \mathrm{U}$ and ${ }^{226} \mathrm{Ra}$ (PREUSSER of Degering 2007). Potassium content of the polymineral samples was set to $12.5 \pm 1.0 \%$ following the estimates of Huntley \& BARIL (1997). An a-value (efficiency of alpha particles in causing radiation damage) of $0.05 \pm 0.01$ was used for the polymineral fraction (Preusser 1999) and $0.03 \pm 0.01$ for the quartz fraction (MAuz et al. 2006). Dose rates, including the cosmogenic contribution, were calcu-

Table 2: Luminescence protocols used for the dating of loess samples. OSL was applied to quartz, IR50 was applied to polyminerals. OSL: stimulation with blue LEDs, IRSL: stimulation with IR LEDs. 1: Omitted in 1st cycle to measure Ln, 2: only applied in last cycle.

\begin{tabular}{lll}
\hline Observed & OSL & IR50 \\
\hline & ${ }^{1}$ Dose & ${ }^{1}$ Dose \\
& Preheat at $230^{\circ} \mathrm{C}$ for $10 \mathrm{~s}$ & Preheat at $250^{\circ} \mathrm{C}$ for $60 \mathrm{~s}$ \\
& ${ }^{2} \mathrm{RSL}$ at $50^{\circ} \mathrm{C}$ for $60 \mathrm{~s}$ & \\
\hline $\mathrm{Ln} / \mathrm{Lx}$ & $\mathrm{OSL}$ at $125^{\circ} \mathrm{C}$ for $60 \mathrm{~s}$ & IRSL at $50^{\circ} \mathrm{C}$ for $300 \mathrm{~s}$ \\
& $\operatorname{Test}_{\text {dose }}$ & Test dose \\
\hline $\mathrm{Tn} / \mathrm{Tx}$ & Preheat at $230^{\circ} \mathrm{C}$ for $10 \mathrm{~s}$ & Preheat at $250^{\circ} \mathrm{C}$ for $60 \mathrm{~s}$ \\
\hline
\end{tabular}


lated using the ADELE software. Water content was set stable over time to the measured value with an uncertainty of $5 \%$ of dry mass.

Luminescence measurements were made on automated Risø TL/OSL DA-20 readers equipped with 9235QA photomultiplier tubes. Palaeodoses were determined using modified single-aliquot regenerative-dose (SAR) protocols (Table 2). Feldspar contamination of the quartz fraction was monitored using the IR-depletion ratio but no contamination was detected in any of the samples. Dose response curves were fitted using a single saturating exponential function for both quartz and feldspar, none of which was close to saturation. A measurement error of $1.5 \%$ was included in the $D_{\mathrm{e}}$ determination and the error on curve fitting is included. For age calculation the Central Age Model (CAM) was used.

Feldspar is known to lose some of its signal with time, referred to as 'anomalous fading' that can be estimated in the laboratory and a correction has been suggested (HuNTLEY \& LAMOTHE 2001). However, the correction is only valid for doses within the linear part of the dose response curve, whereas the samples of this study are beyond that range. Furthermore fading tests have been questioned, as they apparently show laboratory artefacts rather than the fading observed in nature (Lowick et al. 2012). Nevertheless, fading tests were performed on two samples revealing fading rates of $g=1.9 \pm 0.2 \%$ (Möh 2) and $3.1 \pm 0.5 \%$ per decade (Möh 6). Considering the above-mentioned limitations of the fading tests and correction, however, no correction for fading was carried out.

\section{Results}

Dating results are given in Table 1. The age of sample Möh 1 (OSL: $19.5 \pm 1.8 \mathrm{ka}$, IR50: $19.1 \pm 1.6 \mathrm{ka}$ ) is distinctively younger than samples Möh 2, 3, and 4, which have indistinguishable OSL and IR50 ages of ca. $33 \pm 3 \mathrm{ka}$. The consistency of OSL and IRSL ages implies that fading does not significantly affect these samples. Sample Möh 5 is more difficult to interpret, as the IR50 age is significantly older than the OSL age, which again is indistinguishable from the samples overlying Möh 5. Sample Möh 6 is significantly older than the other samples, with an age difference between OSL $(68.1 \pm 6.9 \mathrm{ka})$ and IR50 (58.1 $\pm 5.9 \mathrm{ka})$. The fact that IR50 yields a younger age than OSL could indicate signal loss (fading) in the polymineral fraction, but it is inexplicable why this is not observed for any of the other samples. In this case favour should be given to the OSL. There is a substantial time lag between the samples Möh 2-5 and Möh 6 indicating a stop in loess accumulation. The decalcified layer between 5.9 and $6.2 \mathrm{~m}$ lies just between the two samples Möh 5 and Möh 6 (Fig. 3). Decalcification probably happened accordingly in the time window missing in the loess accumulation record.

\section{Discussion and conclusions}

The drill core penetrating the 'Rissian Moraine' of Möhliner Feld did not reveal glacigenic material. While the origin of the morphology of these shallow ridges is not completely solved, interpreting theses as aeolian dunes appears likely (cf. Pye 1995). First loess accumulation occurred during MIS 4, a period when glaciers likely advanced into the Western and Central Swiss Alpine Foreland (Preusser et al. 2007). A hiatus after ca. $60 \mathrm{ka}$ is identified by luminescence dating and supported by a decalcified layer in the core. The stop in loess accumulation is interpreted to be caused by warmer climate, when vegetation cover stabilised dust in the source area. Decalcification likely represents initial soil formation. Interstadial conditions at the time of the hiatus at Möhliner Feld are also identified at other sites in Switzerland and in loess records of Central Europe (cf. PREUSSER 2004). Main loess accumulation at Möhliner Feld took place around $33 \mathrm{ka}$ in latest MIS 3. This seems to slightly antedate the end of soil formation in the interstadial complexes found in the Swiss Lowlands and in loess records. The uppermost age estimate of ca. 19 ka indicates loess deposition also shortly after the last glacier advance into the foreland.

Considering the age of the MEG, the luminescence ages presented here clearly show that the loess cover was deposited during the Late Pleistocene. This implies a minimum age of MIS 6 for the underlying till originating from the Black Forest (i.e. the Wehra Glacier). In contrast to the assumptions of SchreINER (1995), ice from the Black Forest may have crossed the Rhine Valley during the Rissian. The lower, alpine till at Bünten (MEG), separated by a palaeosol from the upper till (Fig. 2), hence likely pre-dates MIS 6, but there appears no evidence to support an early Middle Pleistocene age, as suggested by SCHLÜCHTER (2004).

\section{Acknowledgements}

Thomas Kim is thanked for allowing the drilling on his property. Thomas Zimmermann, Gemeindeschreiber, Gemeinde Wallbach showed great interest and organised press releases on the drilling. Michael Schnellmann, National Cooperative for the Disposal of Radioactive Waste (Nagra), is thanked for providing finances covering the drilling costs. Christian Schlüchter provided help and discussion on the interpretation of the drill core. High-resolution $\gamma$-spectrometry was carried out by Sönke Szidat, Department of Chemistry and Biochemistry, University of Bern. $\mathrm{C}_{\text {total }}$ measurements were done by Julijana $\mathrm{Kr}$ banjevic. Dorian Gaar was funded through Swiss National Science Foundation (SNF) projects 200021_126784 and 200020_144456.

\section{References}

Dick, K., Graf, H. R., Müller, B. U., Hartmann, P. \& Schlüchter, C. (1996): Das nordalpine Wasserschloss und seine eiszeitgeologische Umgebung. - Eclogae Geologicae Helvetiae, 89: 635-645.

Frechen, M., Schweitzer, U. \& Zander. A. (1996): Improvements in smaple preparation for the fine grain technique. - Ancient TL, 14: $15-17$.

Graf, H. R. (2009): Stratigraphie von Mittel- und Spätpleistozän in der Nordschweiz. - 198 pp.; Wabern (Landesgeologie).

Huntley, D. J. \& BARIL, M. R. (1997): The K content of the K-feldspars beeing measured in optical dating or in thermoluminescence dating. - Ancient TL, 15: 11-14.

Huntley, D. J. \& LAMOTHE, M. (2001): Ubiquity of anomalous fading in Kfeldspars and the measurement and correction for it in optical dating. - Canadian Journal of Earth Sciences, 38: 1093-1106.

KulIG, G., 2005, Erstellung einer Auswertesoftware zur Altersbes-timmung mittels Lumineszenzverfahren unter spezieller Berücksichtigung des 
Einflusses radioaktiver Ungleichgewichte in der ${ }^{238} \mathrm{U}$-Zerfallsreihe. Technische Bergakademie Freiberg, unpublished BSc thesis.

Lowick, S. E., Trauerstein, M. $\mho$ Preusser, F. (2012): Testing the application of post IR-IRSL dating to fine grain waterlain sediments. - Quaternary Geochronology, 8: 33-40.

Mauz, B., PAckman, S. \& LANG, A. (2006): The alpha effectiveness in siltsized quartz: New data obtained by single and multiple aliquot protocols. - Ancient TL, 24: 47-52.

Penck, A. \& Brückner, E. (1901-1909): Die Alpen im Eiszeitalter. - 1157 pp.; Leipzig (Tauchnitz).

Preusser, F. (1999): Luminescence dating of fluvial sediments and overbank deposits from Gossau, Switzerland: fine grain dating. - Quaternary Science Reviews, 18: 217-222.

Preusser, F. (2004): Towards a chronology of the Late Pleistocene in the northern Alpine Foreland. - Boreas, 33: 195-210.

Preusser, F., Blei, A., Graf, H. \& Schlüchter, C. (2007): Luminescence dating of Würmian (Weichselian) proglacial sediments from Switzerland: methodological aspects and stratigraphical conclusions. - Boreas, $36: 130-142$.

Preusser, F. \& Degering, D. (2007): Luminescence dating of the Niederweningen mammoth site, Switzerland. - Quaternary International, 164-65: 106-112.

PyE, K. (1995): The nature, origin and accumulation of loess. - Quaternary Science Reviews, 14: 653-667.

SCHLÜCHTER, C. (2004): The Swiss glacial record - A schematic summary. - In: Ehlers, J. \& GibBARD, P. L. (eds.): Developments in Quaternary Sciences: 413-418; Amsterdam (Elsevier).

Schreiner, A. (1995): Zur Quartärgeologie des unteren Wehratales und zur Frage der Vergletscherung des Dinkelberges in der Rißeiszeit. Eiszeitalter und Gegenwart, 45: 62-74. 